\title{
Nefroloji Kliniği, Hemodiyaliz ve Periton Diyalizi Ünitesinde Çalışan Hemşirelerin Periton Diyalizi ile İlgili Algılarının Araştırılması
}

\author{
Investigation of Peritoneal Dialysis Perceptions of \\ Nurses Working in Nephrology Clinic, Hemodialysis \\ and Peritoneal Dialysis Unit
}

\author{
İbrahim DOĞAN ${ }^{1}$, Emel UÇAR ${ }^{2}$, Nur ÜNAL KAYA ${ }^{3}$, Kenan ATEŞ ${ }^{4}$ \\ ${ }^{I}$ Dr. Öğr. Üyesi, Hitit Üniversitesi Tıp Fakültesi, İ̧̧ Hastalıkları Anabilim Dalı, Nefroloji Kliniği, Çorum, Türkiye \\ ${ }^{2}$ Hemşire, Baxter, Türkiye \\ ${ }^{3}$ Diyaliz Hemşiresi, Hitit Üniversitesi, Erol Olçok Eğitim ve Araştırma Hastanesi, Periton Diyaliz Ünitesi, \\ Çorum, Türkiye \\ ${ }^{4}$ Prof. Dr., Ankara Üniversitesi Tıp Fakültesi, İç Hastalıkları Anabilim Dalı, Nefroloji Kliniği, Ankara, Türkiye
}

Geliş Tarihi: 12 Ağustos 2019

Kabul Tarihi: 19 Kasım 2019

\section{İletişim / Correspondence:}

İbrahim DOĞAN

E-posta:

dr.ibrahimdogan@hotmail.com

\section{Özet}

Giriș: Renal replasman tedavisinin seçiminde nefroloji, hemodiyaliz ve periton diyalizi hemşirelerinin algısı çok önemlidir. Bu çalışmada nefroloji kliniği, hemodiyaliz ve periton diyalizi ünitelerinde çalışan hemşirelerin periton diyaliz ile ilgili algılarının araştırılması amaçlanmıştır.

Gereç ve Yöntem: Çalışma altı ilde 15 ayrı klinikte/ünitede yapılmıştır. Çalışmaya 60'1 nefroloji kliniği, 99'u hemodiyaliz ve 32'si periton diyalizi ünitesinde çalışan 191 hemşire alınmıştır. Katılımcıların \%16.2'si lise, \%78.5'i üniversite ve \%5.2'si yüksek lisans mezunudur. Katılımcıların \%51.8'i üniversite hastanesi, \%34.6'sı devlet hastanesi, \%13.6'sı özel kurumda çalışmaktadır. Her bir katılımcıya, yedisi sosyodemografik içerikli olmak üzere toplam 45 sorudan oluşan anket uygulanmıştır.

Bulgular: Periton diyalizi hemşirelerinin \%96.8'i hastaların renal replasman tedavisi seçimi konusunda hemşirenin görüşünü aldığını belirtirken, nefroloji hemşirelerinde bu oran \%63.3, hemodiyaliz hemşirelerinde ise \%62.6 olarak bulunmuştur $(p=0.003)$. Hemşireler periton diyaliz tedavisinin diğer renal replasman tedavilerine göre daha az uygulanıyor olmasının nedenlerini hasta ve yakınının sorumluluk almak istememesi ve hastanın bilgilendirilmemesi olarak belirtmişlerdir.

Yakınlarında diyaliz gereksinimi olduğunda periton diyalizi tedavisini tercih etme oranı periton diyalizi hemşirelerinde $\% 87.5$, nefroloji hemşirelerinde $\% 51.7$ ve hemodiyaliz hemşirelerinde $\% 45.5$ bulunmuştur. Periton diyalizi uygulanma oranı sorulduğunda her üç grupta da en yüksek oranda yanıt \%0-10 arasındayken, bu oranın ne olması gerektiği sorusuna periton diyalizi hemşirelerinin $\% 62.5$ ' $\mathrm{i}$, hemodiyaliz hemşirelerinin \%31.3'ü, nefroloji hemşirelerinin \%28.3’ü “\%30'un üzerinde olmalıdır." şeklinde yanıt vermişlerdir. 
Sonuç: Nefroloji ve hemodiyaliz hemşirelerinin periton diyalizi ile ilgili algılarının olumlu yönde olmadığı ve bu konuda bilgi eksikliklerinin olduğu ortaya çıkmıştır. Hemşirelerin eğitim sonrası periton diyalizi ile ilgili algılarının değişeceği ve bunun da hastaların periton diyalizi tedavisini seçmesine olumlu katk1 sağlayabileceği düşünülmüştür.

Anahtar Kelimeler: Kronik Böbrek Hastalığı; Diyaliz; Periton Diyalizi; Nefroloji Hemşireliği.

\begin{abstract}
Introduction: Nephrology, peritoneal dialysis and hemodialysis nurses' perception of renal replacement therapy is very important. In this study, we aimed to investigate the peritoneal dialysis perceptions of nurses working in nephrology clinic, peritoneal dialysis and hemodialysis units.
\end{abstract}

Material and methods: The study was performed in 15 different clinics/units. The study included 191 nurses, 60 of whom worked in nephrology clinics, 99 of hemodialysis units, and 32 of peritoneal dialysis units. $16.2 \%$ of the participants were high school graduates, $78.5 \%$ were university graduates and $5.2 \%$ were graduate. $51.8 \%$ of the participants were working in university hospitals, $34.6 \%$ in public hospitals and $13.6 \%$ in private institutions. A total of 45 questions, 7 of which were sociodemographic, were applied to each participant.

Results: While $96.8 \%$ of the peritoneal dialysis nurses received the opinion of the nurse about the RRT selection, this rate was $63.3 \%$ in nephrology nurses and $62.6 \%$ in hemodialysis nurses $(p=0.003)$. The nurses stated that the patient and his/her relatives did not want to take responsibility and the patient was not informed about the peritoneal dialysis treatment being applied less than other renal replacement therapies.

Peritoneal dialysis nurses had 87.5\%, nephrology clinic nurses $51.7 \%$ and hemodialysis nurses $45.5 \%$ peritoneal dialysis response to the question of which method they would prefer when their relatives needed dialysis. When asked about the rate of peritoneal dialysis, the highest rate of answer was $0-10 \%$ in all three groups, $62.5 \%$ of peritoneal dialysis nurses, $31.3 \%$ of hemodialysis nurses and $28.3 \%$ of nephrology clinic nurses, should be above $30 \%$ in response to the question of what rate should be applied peritoneal dialysis.

Conclusion: It was revealed that the perceptions of nephrology and hemodialysis nurses about peritoneal dialysis were not positive and there was a lack of information on this subject. We believe that the nurses 'perceptions about peritoneal dialysis will change after their education and this may contribute positively to patients' choice of peritoneal dialysis treatment.

Keywords: Chronic Kidney Disease; Dialysis; Peritoneal Dialysis; Nephrology Nursing

\section{GÍRİs}

Tüm dünyadaki ölümlerin yaklaşık \%63'ünden kronik hastalıkların sorumlu olduğu bilinmektedir (1). Böbrek işlevlerinin geri dönüşümsüz kaybı olarak tanımlanan kronik böbrek hastalığ 1 (KBH) önemli bir toplum sağlığı problemidir. Dünyadaki prevalansının \%8-16 arasında olduğu gösterilmiş (2) olan KBH'nin ülkemizdeki prevalansının \%15.7 olduğu Chronic REnal Disease In Turkey (CREDIT) çalışmasıyla saptanmıştır (3). Toplumda yüksek KBH prevalansının nedeninin diabetes mellitus, hipertansiyon gibi kronik hastalık, kardiyovasküler hastalı, obezite ve yaşlı nüfus oranının giderek artması olduğu düşünülmektedir (4).

Kronik böbrek hastalı̆̆ 1 serum kreatinin bazlı glomerüler filtrasyon hızı tahminine göre beş evrede sinıflandırılmaktadır. Glomerüler filtrasyon hizının $<15 \mathrm{ml} / \mathrm{dk} / 1.73 \mathrm{~m}^{2}$ olması son dönem böbrek yetmezliği (SDBY) olarak adlandırılmaktadır (5). Bu evrede kaybedilen böbrek işlevini yerine koymak için renal 
replasman tedavisi (RRT) seçenekleri düşünülmelidir. RRT seçenekleri renal transplantasyon, hemodiyaliz (HD), ev HD'si ve periton diyalizi (PD)'dir (5).

Renal replasman tedavi seçeneklerinin başında renal transplantasyon gelmesine karşın nakil yapılabilecek organ sayısının kisitlı olmas1 nedeniyle diyaliz yöntemleri halen en yaygın kullanılan RRT seçenekleridir. Hemodiyaliz ve PD yöntemlerinin avantajları ve dezavantajları açısından birbirlerine üstünlükleri olmakla beraber genelde birbirlerine geçişlidirler. Periton diyalizi tedavisi, toplam tedavi süresinin sinırlı olması ve hastanın kendi tedavisinde daha aktif rol oynaması nedeniyle HD tedavisine göre daha az uygulanmaktadır. Son y1llarda PD'nin uygulanma oranı gittikçe azalmaktadır. Ülkemizde 2008 yilında 6109 olan PD hasta sayısının 2017 y1lında 3346 hastaya kadar düştüğü görülmektedir (6).

Renal replasman tedavisi gerektiren SDBY durumunda hastalara her üç yöntem ile ilgili ayrıntılı bilgi verilmektedir. Renal transplantasyon şansı olmayan veya verici adayı bulunmayan hastalara PD veya HD kararı vermeleri için eğitim genelde doktor veya bu konu ile ilgili deneyimli bir hemşire tarafından verilmektedir. Hastaların SDBY geliştiğinde oluşan biyokimyasal, fiziksel ve ruhsal sorunlarının yanında, yeterli düzeyde bilgi sahibi olmadıkları bir alanda geleceği ile ilgili karar vermesi kolay olmamaktadır. $\mathrm{Bu}$ süreçte tedavi seçeneklerini anlatacak kişinin bilgi düzeyi ve bilgiyi aktarış şekli önemli olmaktadır. Renal replasman tedavisinin seçiminde sürecin başından itibaren hastanın yanında olan, tedavi geçiş aşaması dahil olmak üzere tüm aşamalarda ve hasta gereksinim duyduğunda hasta ile iletişim ve temasta bulunan, eğitici ve danışman rolünü üstlenen nefroloji, $H D$ ve $P D$ hemşirelerinin RRT seçenekleri ile ilgili algıları çok önemlidir (7).

$\mathrm{Bu}$ çalışmada nefroloji kliniği, $\mathrm{HD}$ ve $\mathrm{PD}$ ünitesinde çalışan hemşirelerin PD ile ilgili algılarının araştııılması amaçlanmıştır.

\section{GEREC VE YÖNTEM}

Çalışma 2014 yılında altı farklı ilde gerçekleştirilmiştir. Çalışmaya 15 ayrı nefroloji kliniğinde çalışan 60 hemşire, $10 \mathrm{HD}$ ünitesinde çalışan 99 hemşire ve 26 PD ünitesinde çalışan 32 hemşire olmak üzere toplamda 191 hemşire alınmıştır. Çalışmanın yapıldığı kurumlardan izin alındıktan sonra, Ocak-Haziran 2014 tarihleri arasında araştırma verileri toplanmıştır. Her bir katılımcıya toplam 45 sorudan oluşan anket uygulanmıştır. Anket formu, ilgili güncel kılavuzlar eşliğinde araştırmacılar tarafından hemşirelerin periton diyaliz ile ilgili bilgi düzeylerini ölçmeye yönelik olarak hazırlanmıştır. Anketin ilk bölümünde hemşirelerin yaş, cinsiyet, eğitim durumları, çalıştıkları kurum, sertifikalı olma durumu, yakın çevresinde diyaliz tedavisi alan kişilerin bulunma durumu ve PD eğitimi alma durumları ile ilgili sosyodemografik içerikli yedi soru yer almaktadır. Anket HD ve PD'nin klinik özellikleri, yaşam kalitesi üzerindeki etkileri ve birbirlerine üstünlükleri ile ilgili 14 klinik tanımlayıcı soru, PD'nin az uygulanıyor olması ile ilgili 11 soru, PD uygun olan hasta gruplarının değerlendirildiği 10 soru ile ülkemizde PD'nin uygulanma oranı ve süresini içeren üç soruyu içermektedir. Araştırmaya katılmayı kabul eden hemşirelere çalışma ortaminda veri toplama formları verilerek doldurmaları istenmiştir.

Etik kurul onayı Ankara Eğitim ve Araştırma Hastanesi Eğitim Planlama ve Koordinasyon Kurulu'ndan 25.09.2013 tarih ve 520 sayı numarası ile alınmıştır. Çalışmaya alınan hemşirelerin tümünden yazılı onam alınmıştır.

\section{Istatistiksel Analiz}

Hesaplamalarda SPSS for Windows paket programı (SPSS Inc., Chicago, IL, ABD version 22.0, Hitit Üniversitesi lisanslı) kullanılmıştır. Yaş değişkeninin normal dağılıp dağılmadığını saptamak için Shapiro Wilk testi uygulanmıştır. Kesitli değişkenlerin analizinde ki-kare veya Fisher kesin ki-kare testi kullanılmıştır. Yaş değişkeni normal dağılım gösterdiği için ortalama \pm standart sapma şeklinde verilmiştir. $p$ değeri < 0.05 istatistiksel olarak anlamlı kabul edilmiştir.

\section{BULGULAR}

Kat1lımcıların 182'si (\%95.3) kadındır, 31'i (\%16.2) lise, 150'si (\%78.5) üniversite ve 10'u $(\% 5.2)$ yüksek lisans mezunudur. Hemşirelerin 99 'u (\%51.8) üniversite hastanesi, 66's1 (\%34.6) 
devlet hastanesi, 26's1 (\%13.6) özel kurumda çalışmaktadır. Katılımcıların 66'sı (\%34.6) RRT ile ilgili herhangi bir sertifikaya sahip değildir. Çalışmaya katılan hemşirelerin 43'ünde (\%25) yakın çevresinde diyaliz tedavisi alan birinin olduğu saptanmıştır. Katılımcıların sosyodemografik veri özellikleri Tablo 1'de sunulmuştur. Periton diyalizi hemşirelerinin yaş ortalaması nefroloji kliniği ve HD hemşirelerinden daha yüksek saptanmıştır (sırasıyla $p<0.001, p=$ 0.013). Ayrıca PD hemşirelerinin tümü sertifika sahibiyken bu oran nefroloji klinik hemşirelerinde $\% 23.3$, HD hemşirelerinde ise $\% 79.9$ olarak saptanmıştır $(p<0.001)$. Eğitim düzeylerine bakıldığında PD hemşirelerinin eğitim almış olma oranı \%96.9 ile en yüksek iken bu oran nefroloji klinik hemşirelerinde \%40, HD hemşirelerinde ise \%83.8 olarak saptanmıştır ( $p<$ 0.001).

Periton diyalizi hemşirelerinin \%96.8'i hastaların RRT seçimi konusunda hemşirenin görüşünü aldığını belirtirken, nefroloji hemşirelerinde bu oran \%63.3, HD hemşirelerinde ise \%62.6 olarak saptanmıştır $(p=0.003)$. Periton diyalizi hemşi- releri \%96.9 oranında "Tedavi seçimine hasta karar verici olmalıdır" derken bu oran nefroloji hemşirelerinde \%93.6, HD hemşirelerinde ise $\% 82.8$ 'dir $(p=0.04)$. Tüm hemşireler hasta tedavi seçiminde önemsedikleri parametreler sorusuna yanıt olarak ilk sırada yaşam kalitesi verileri, ikinci sırada sağ kalım verileri demişlerdir. En iyi başlangıç diyaliz yöntemi sorulduğunda PD hemşirelerinin \%96.9'u, nefroloji hemşirelerinin \%63.3'ü, HD hemşirelerinin ise \%55.6's1 PD olarak yanıtlamışlardır. Hangi diyaliz yönteminde böbrek nakli olma olasılığının daha kolay olduğu ile ilgili soruda ise PD hemşirelerinin \%84.4'ü, nefroloji hemşirelerinin \%46.7'si, HD hemşirelerinin ise \%38.4'ü PD olarak yanıtlamışlardır. Hemşirelere yönelik klinik bilgi sorularına verilen yanitlar Tablo 2'de sunulmuştur.

Hemşirelere göre PD tedavisinin diğer RRT'lere göre daha az uygulanıyor olmasının nedenlerini içeren yanitlar Tablo 3 'te sunulmuştur. Bu sonuçlara ait nedenleri ise hasta ve yakınının sorumluluk almak istememesi ve hastanın bilgilendirilmemesi olarak bildirmişlerdir.

Tablo 1. Nefroloji, Hemodiyaliz ve Periton Diyalizi Hemşirelerinin Sosyodemografik Özelliklerinin Dağılımı

\begin{tabular}{|c|c|c|c|c|}
\hline & $\begin{array}{l}\text { Nefroloji } \\
\text { Hemşiresi }\end{array}$ & $\begin{array}{c}\text { Hemodiyaliz } \\
\text { Hemşiresi }\end{array}$ & $\begin{array}{l}\text { Periton Diyalizi } \\
\text { Hemşiresi }\end{array}$ & $p$ \\
\hline & $\overline{\mathrm{x}} \pm \mathrm{SS}$ & $\overline{\mathrm{x}} \pm \mathrm{SS}$ & $\overline{\mathrm{x}} \pm \mathrm{SS}$ & \\
\hline \multirow[t]{2}{*}{ Yaş (yıl) } & $32.4 \pm 6.8$ & $34.3 \pm 7.7$ & $38.4 \pm 5.07^{\mathrm{a}}$ & 0.001 \\
\hline & $\mathrm{n}$ & $\mathrm{n}$ & $\mathrm{n}$ & \\
\hline Cinsiyet (Kadın/Erkek) & $59 / 1$ & $92 / 7$ & $31 / 1$ & $0.344^{*}$ \\
\hline $\begin{array}{l}\text { Eğitim Durumu } \\
\text { Lisans } \\
\text { Üniversite } \\
\text { Yüksek Lisans }\end{array}$ & $\begin{array}{c}8 \\
46 \\
6\end{array}$ & $\begin{array}{c}21 \\
75 \\
3\end{array}$ & $\begin{array}{c}2 \\
29 \\
1\end{array}$ & $0.092^{*}$ \\
\hline $\begin{array}{l}\text { Çalıştığı Kurum } \\
\text { Üniversite } \\
\text { Devlet Hastanesi } \\
\text { Özel Kurum }\end{array}$ & $\begin{array}{c}38 \\
22 \\
0\end{array}$ & $\begin{array}{l}46 \\
30 \\
23\end{array}$ & $\begin{array}{c}15 \\
14 \\
3\end{array}$ & $<0.001^{*}$ \\
\hline Sertifika (Var/Yok) & $14 / 46$ & $79 / 20$ & $32 / 0$ & $<0.001$ \\
\hline $\begin{array}{l}\text { Yakın çevresinde diyaliz } \\
\text { tedavisi alan (Var/Yok) }\end{array}$ & $15 / 45$ & $20 / 79$ & $8 / 24$ & 0.730 \\
\hline $\begin{array}{l}\text { Eğitim alma durumu } \\
\text { (Var/Yok) }\end{array}$ & $24 / 36$ & $83 / 16$ & $31 / 1$ & $<0.001$ \\
\hline Toplam & 60 & 99 & 32 & \\
\hline
\end{tabular}

${ }^{a}$ Grup1 ile $3 p<0.001$, grup 2 ile $3 p=0.013$,

* Fisher's Exact Test 
Hemşirelere PD tedavisine uygun hasta grupları sorulduğunda benzer dağılımlarda yanıt vermişlerdir. $\mathrm{Bu}$ sorulara verilen yanitlar Tablo 4'te sunulmuştur. Nefroloji ve HD hemşireleri daha çok genç hastaların ve damar girişim yolu problemi olan hastaların PD tedavisi için uygun olduğunu belirtmişlerdir. Bir yakınında $\mathrm{KBH}$ gelişirse PD tedavisini tercih etme oranı PD hemşirelerinde \%87.5, nefroloji hemşirelerinde $\% 51.7$, HD hemşirelerinde \%45.5 bulunmuştur.

Hemşirelere ülkemizdeki tedavi seçenekleri arasında PD uygulanma oranı sorulduğunda PD hemşirelerinin $\% 75$ 'i, HD hemşirelerinin $\% 47.5$ 'i ve nefroloji hemşirelerinin $\% 43.4$ 'ü $\% 0-10$ arası oranlarında yanıt vermişlerdir. $\mathrm{Bu}$ oranın ne olması gerektiği sorulduğunda PD hemşirelerinin $\% 62.5$ 'i, HD hemşirelerinin \%31.3'ü, nefroloji hemşirelerinin \%28.3'ü \%30 üzeri olarak yanıtlamışlardır. Periton diyalizinin ne kadar sürdürülebileceğini $\mathrm{PD}$ hemşirelerinin \%56.3'ü ve nefroloji hemşirelerinin \%51.7'si 5-10 yil aras1, HD hemşirelerinin \%32.3'ü 3-5 y1l aras1 olarak belirtmişlerdir (Tablo 5).

Tablo 2. Nefroloji, Hemodiyaliz ve Periton Diyalizi Hemşirelerinin Klinik Parametreler ile İlgili Sorulara Periton Diyalizi Lehine Verdikleri Yanıtların Dağılımı

\begin{tabular}{|c|c|c|c|}
\hline & $\begin{array}{l}\text { Nefroloji } \\
\text { Hemşiresi } \\
(n=60)\end{array}$ & $\begin{array}{l}\text { Hemodiyaliz } \\
\text { Hemşiresi } \\
(n=99)\end{array}$ & $\begin{array}{l}\text { Periton } \\
\text { Diyalizi } \\
\text { Hemşiresi } \\
(\mathbf{n}=32)\end{array}$ \\
\hline & $\%$ & $\%$ & $\%$ \\
\hline Sizce en iyi başlangıç diyaliz yöntemi hangisidir? & 63.3 & 55.6 & 96.9 \\
\hline Sizce en iyi uzun süreli diyaliz yöntemi hangisidir? & 35 & 23.2 & 65.6 \\
\hline $\begin{array}{l}\text { Sizce diyaliz yöntemlerinin hangisinde erken dönem hasta sağ kalımı } \\
\text { daha iyidir? }\end{array}$ & 61.7 & 31.3 & 93.8 \\
\hline $\begin{array}{l}\text { Sizce diyaliz yöntemlerinin hangisinde uzun dönem hasta sağ kalımı } \\
\text { daha iyidir? }\end{array}$ & 46.7 & 34.3 & 46.9 \\
\hline $\begin{array}{l}\text { Sizce diyaliz yöntemlerinin hangisinde böbrek nakli olma olasılığı } \\
\text { yüksektir? }\end{array}$ & 46.7 & 38.4 & 84.4 \\
\hline Sizce diyaliz yöntemlerinin hangisinde malnütrisyon sıklığı yüksektir? & 31.7 & 25.3 & 59.4 \\
\hline $\begin{array}{l}\text { Sizce diyaliz yöntemlerinin hangisinde rezidüel renal fonksiyon daha } \\
\text { uzun süre korunur? }\end{array}$ & 68.3 & 58.6 & 96.9 \\
\hline $\begin{array}{l}\text { Sizce diyaliz yöntemlerinin hangisinde volüm kontrolü daha iyi } \\
\text { sağlanır? }\end{array}$ & 41,7 & 42.4 & 84.4 \\
\hline Sizce diyaliz yöntemlerinin hangisinde anemi daha iyi kontrol edilir? & 63.3 & 72.7 & 96.9 \\
\hline Sizce diyaliz yöntemlerinin hangisinde diyet daha esnektir? & 61.7 & 75.8 & 96.9 \\
\hline $\begin{array}{l}\text { Sizce diyaliz yöntemlerinin hangisinde enfeksiyon sıklığı daha } \\
\text { yüksektir? }\end{array}$ & 61.7 & 76.8 & 40.6 \\
\hline Sizce diyaliz yöntemlerinin hangisinde hasta yaşam kalitesi daha iyidir? & 76.7 & 68.7 & 96.9 \\
\hline $\begin{array}{l}\text { Sizce diyaliz yöntemlerinin hangisinde hasta memnuniyet oranı daha } \\
\text { yüksektir? }\end{array}$ & 63.3 & 57.6 & 96.9 \\
\hline $\begin{array}{l}\text { Sizce diyaliz yöntemlerinin hangisinde kullanılan ilaçlar dahil toplam } \\
\text { tedavi maliyeti daha yüksektir? }\end{array}$ & 13.3 & 6.1 & 3.1 \\
\hline
\end{tabular}


Tablo 3. Nefroloji, Hemodiyaliz ve Periton Diyalizi Hemşirelerinin Periton Diyalizi Tedavisinin Az Uygulanıyor Olma Nedenleri Sorusuna Verdikleri Yanıtların Dağılımı

\begin{tabular}{|l|c|c|c|}
\hline & $\begin{array}{c}\text { Nefroloji } \\
\text { Hemşiresi } \\
(\mathbf{n = 6 0 )}\end{array}$ & $\begin{array}{c}\text { Hemodiyaliz } \\
\text { Hemşiresi } \\
\text { (n=99) }\end{array}$ & $\begin{array}{c}\text { Periton } \\
\text { Diyalizi } \\
\text { Hemşiresi } \\
\text { (n=33) }\end{array}$ \\
\cline { 2 - 4 } & $\%$ & $\%$ & 78.1 \\
\hline Hastanın yeterince bilgilendirilmemesi & 60 & 58.6 & 31.3 \\
\hline Tedavi ekibinin PD konusunda deneyim eksikliği & 41.7 & 28.3 & 90.6 \\
\hline Hastanın sorumluluk almak istememesi & 80 & 77.8 & 84.4 \\
\hline Hasta yakınının sorumluluk almak istememesi & 63.3 & 61.6 & 56.3 \\
\hline Hekimlerin PD ile uğraşmak istememesi & 21.7 & 28.3 & 81.3 \\
\hline Komplikasyon yaşayan olumsuz PD örnekleri & 53.3 & 65.7 & 56.3 \\
\hline Hastanın imaj kaygısı & 63.3 & 61.6 & 71.9 \\
\hline Hemodiyaliz merkezlerinin çoğalması & 41.7 & 36.4 & 68.8 \\
\hline Hemodiyaliz merkezlerinin etik dıșı yaklaşımı & 33.3 & 37.4 & 53.1 \\
\hline Kuruma maddi getirisinin HD'den az olması & 15 & 24.2 & 59.4 \\
\hline Devlet tarafından teşvik edilmemesi & 30 & 29.3 & \\
\hline
\end{tabular}

Tablo 4. Nefroloji, Hemodiyaliz ve Periton Diyalizi Hemşirelerinin Periton Diyalizi Tedavisi için Uygun Görülen Hasta Grupları Sorusuna Verdikleri Yanıtların Dağılımı

\begin{tabular}{|l|c|c|c|}
\hline & $\begin{array}{c}\text { Nefroloji } \\
\text { Hemşiresi } \\
(\mathbf{n = 6 0}\end{array}$ & $\begin{array}{c}\text { Hemodiyaliz } \\
\text { Hemşiresi } \\
\text { (n=99) }\end{array}$ & $\begin{array}{c}\text { Periton } \\
\text { Diyalizi } \\
\text { Hemşiresi } \\
\text { (n=32) }\end{array}$ \\
\cline { 2 - 4 } & $\%$ & $\%$ & 93.8 \\
\hline Çocuk hastalar & 43.3 & 42.4 & 96.9 \\
\hline Genç hastalar & 76.7 & 68.7 & 56.3 \\
\hline Yaşlı hastalar & 10 & 13.1 & 65.6 \\
\hline Diyabetik hastalar & 15 & 17.2 & 90.6 \\
\hline Kardiyovasküler hastalığı olan hastalar & 25 & 31.3 & 50 \\
\hline Volüm kontrolünde güçlük çekilen hastalar & 20 & 37.4 & 100 \\
\hline Rezidüel renal fonksiyonu olan hastalar & 33.3 & 34.3 & 87.5 \\
\hline Diyalize yeni başlayan hastalar & 60 & 53.5 & 87.5 \\
\hline Böbrek nakline uygun hastalar & 43.3 & 27.3 & 96.9 \\
\hline Damar giriş yeri sorunu olan hastalar & 66.7 & 76.8 & \\
\hline
\end{tabular}


Tablo 5. Nefroloji, Hemodiyaliz ve Periton Diyalizi Hemşirelerinin Periton Diyalizi Uygulama Oranları ve Süresi ile İlgili Sorulara Verdikleri Yanıtların Dağılımı

\begin{tabular}{|c|c|c|c|}
\hline & $\begin{array}{c}\text { Nefroloji } \\
\text { Hemşiresi } \\
(n=60)\end{array}$ & $\begin{array}{l}\text { Hemodiyaliz } \\
\text { Hemşiresi } \\
(n=99)\end{array}$ & $\begin{array}{c}\text { Periton } \\
\text { Diyalizi } \\
\text { Hemşiresi } \\
(\mathbf{n}=\mathbf{3 2})\end{array}$ \\
\hline & $\%$ & $\%$ & $\%$ \\
\hline $\begin{array}{l}\text { Sizce ülkemizde PD uygulama oranı nedir? (\%) } \\
0-10 \\
10-20 \\
20-30 \\
30 \text { üstü } \\
\text { Yanıtsız }\end{array}$ & $\begin{array}{c}43.4 \\
35 \\
10 \\
3.3 \\
8.3\end{array}$ & $\begin{array}{c}47.5 \\
26.3 \\
16.2 \\
3 \\
7.1\end{array}$ & $\begin{array}{c}75 \\
25 \\
- \\
- \\
-\end{array}$ \\
\hline $\begin{array}{l}\text { Sizce ülkemizde PD tedavi oranı ne olmalıdır? (\%) } \\
0-10 \\
10-20 \\
20-30 \\
30 \text { üstü } \\
\text { Yanıtsız } \\
\end{array}$ & $\begin{array}{c}15 \\
25 \\
23.3 \\
28.3 \\
8.3\end{array}$ & $\begin{array}{c}11.2 \\
21.2 \\
27.3 \\
31.3 \\
9.1\end{array}$ & $\begin{array}{c}9.4 \\
6.2 \\
21.9 \\
62.5 \\
-\end{array}$ \\
\hline $\begin{array}{l}\text { Sizce PD tedavisi ne kadar sürdürülebilir? (yıl) } \\
1-3 \text { yıl } \\
3-5 \text { yıl } \\
5-10 \text { yıl } \\
10 \text { yıl üzeri } \\
\text { Yanıtsız }\end{array}$ & $\begin{array}{c}13.3 \\
10 \\
51.7 \\
18.3 \\
6.7\end{array}$ & $\begin{array}{c}15.2 \\
32.3 \\
28.3 \\
19.2 \\
5.1\end{array}$ & $\begin{array}{c}6.3 \\
6.3 \\
56.3 \\
31.3 \\
-\end{array}$ \\
\hline
\end{tabular}

\section{TARTIŞMA}

Nefroloji kliniği, HD ve PD ünitesinde çalışan hemşirelerin PD algılarının değerlendirildiği bu çalışmada HD ve nefroloji hemşirelerinin PD ile ilgili düşüncelerinin olumlu olmadığı belirlenmiştir. Ayrıca PD'nin klinik üstünlüklerinin değerlendirildiği sorulara verilen yanttlar doğrultusunda nefroloji ve HD hemşirelerinin PD ile ilgili bilgi ve eğitim eksikliklerinin olduğu, PD uygulama oranları ile ilgili değerlendirmede gerçekçi tahminler yaptıkları ancak PD'nin olması gereken oranı ile gerçek oranlarına verdikleri yanıtlar arasında ciddi farklılıklar olduğu görülmüştür.

Ülkemizde tüm RRT seçenekleri arasında PD tedavisinin oranı giderek azalmaktadır. Türk Nefroloji Derneği kayıtlarına göre Türkiye'de 2017 yılı içerisinde RRT alan hasta prevalansı 77311, insidans1 11837'dir. 2017 y1l içerisinde RRT alan hastalar içerisinde PD prevalans 3346 (\%4.33), insidans1 ise 876 (\%7.4) olarak saptanmıştır (6). Türkiye'de 2001 yılından bu yana sürekli artan bir RRT gerektiren SDBY prevalans1 varken (milyon nüfus başına 2001 y1lında 324, 2017 y1lında 957 hasta) PD hasta oranında ise 2008 y1lından beri devam eden bir düşüş yaşanmaktadır. 2008 y1lında 6109 olan PD hasta sayıs 2016 y1lında 3508 hasta, 2017 yılında ise 3346 hastaya düşmüştür (6). Amerikan Ulusal Böbrek Veri Sistemi (The United States Renal Data System USRDS) verilerine göre ülkemiz PD kullanımı sıralamasında orta düzeyde PD kullanan ülkelerin sırasından az kullanan ülkeler sırasına doğru yaklaşmıştır (6). Bu azalmanın birçok nedeni olabilir. Bunlar arasında daha az tercih edilme (2016 y1linda PD tedavisine yeni başlayan hasta sayısı 1020 iken, 2017'de bu sayı 876 hastadır.), PD hastalarının HD'ye göre daha yüksek oranda nakil olmaları (2017'de bu oran \%6'ya \%3.1 olarak bildirilmiştir) olabilir (6).

Son dönem böbrek yetmezliği hastası tedaviye başlamak için renal transplantasyon, merkez veya ev HD'si veya PD tedavisi için karar vermek durumundadır. Karar verme aşamasında hastanın otonomisi, sosyal koşulları, tedaviye istekliliği ve verilen eğitim etkili olmaktadır $(8,9)$. Hastalar çoğu zaman kendileri için en iyi yöntemin hangi yöntem olduğu ile ilgili ciddi karmaşa yaşamaktadır. Prediyaliz dönemde verilen eğitim hastaların kendilerine en uygun diyaliz türünü seçme- 
sine yardımcı olmaktadır (10). Ayrıca, prediyaliz eğitiminin, RRT bașlamasını geciktirdiğine ve hastanın PD seçimini önemli ölçüde arttırdığına yönelik önemli kanıtlar bulunmaktadır (11).

Son dönem böbrek yetmezliği tanısı almış ve nefroloji multidisipliner ekibi ile karşılaşmış bir hastanın bakımı altında olduğu sağlık personeli grubunun hasta algısı ve tedavi seçimi üzerine etkisi olacağ mada hipotezi doğrulamaya yönelik bir soru ile araştırmaya başlanmıştır. "Hastalar tedavi seçiminde sizin görüşünüzü sorar mı?" sorusuna PD hemşirelerinin çok büyük bir bölümü, nefroloji ve HD hemşirelerinin ise yarısından fazlası "Evet' demişlerdir. Hastalar hemşirelerin görüşüne önem vermektedir. Periton diyalizi tedavisinin klinik avantajları ve yaşam kalitesi üzerine olumlu etkilerinin değerlendirilmesi için sorulan klinik parametreler ile ilgili soruları nefroloji ve HD hemşireleri daha düşük oranda, PD hemşireleri ise beklenildiği gibi daha yüksek oranda PD lehine yanıtlamışlardır. Nefroloji, HD ve PD hemşireleri PD tedavisinin uygulanabileceği hasta grubunu oldukça kısıtlı tutmuş, özellikle genç hastaları ve vasküler girişim yolu problemi nedeniyle başka bir tedavi yöntemi arama zorunluluğu doğmuş hasta grubunu belirtmişlerdir. Ancak KBH hasta yaşının yükseldiği genel popülasyona bakıldığında hemşireler yaşlı hastalarda PD uygunluğu konusunda oldukça çekimser davranmıştır.

Çalışmaya alınan hemşire grupları PD tedavisinin HD'den daha az uygulanıyor olmasını pek çok nedene bağlamışlardır. Bunlar arasında en dikkat çekici olanları hastaların yeterince bilgilendirilmemesi, hastanın ya da yakınının bireysel katılımı ile gerçekleşen bir tedavi olması gerektiği gerçeği ile hasta ve yakınlarının sorumluluk almak istememeleri, daha önce PD tedavisi almış ve yaşadığı komplikasyonlar nedeniyle tedaviden ayrılmış hastaların olumsuz örnek oluşturmalarıdır.

Nefroloji, HD ve hatta PD hemşireleri PD'nin ülkemizde uygulanma oranı ile ilgili gerçek olmayan iyimser rakamlar vermişlerdir. Ancak PD tedavinin uygulanabileceği oranlar ile ilgili verdikleri rakamlar da iyimserdir. Nefroloji ve HD hemşireleri yakınlarına PD'yi daha az oranda önerirken, PD hemşireleri daha yüksek oranda önermektedir. $\mathrm{Bu}$ tercih edilmede önemli nedenler PD hemşirelerinin PD ile ilgili gerekli eğitimi almış olmaları ve PD'nin klinik yararları hakkındaki deneyimlerinin varlığı olabilir.

Sonuç olarak PD tedavisi ile ilgili nefroloji ve HD hemşireleri ile PD hemşireleri arasında klinik bilgi, alg1 ve benimseme oranı açısından önemli düzeyde farklılıklar olduğu görülmektedir. Hemodiyaliz ve nefroloji hemşireleri PD tedavisini güvenilir ve uygulanabilir bulmaktadırlar. Bununla birlikte PD'nin klinik üstünlükleri hakkında bilgi eksiklikleri vardır. Tedaviye uygun görülen hasta gruplarının çok sınırlı tutulmuş olması günümüz PD uygulayan hasta sayısı için açıklayıcı olabilir.

Hastaların tedavisinin her aşamasında yanında bulunan nefroloji ve HD hemşirelerinin PD endikasyonları ve klinik yararı ile ilgili olarak eğitim almalarının bir zorunluluk olduğu görülmektedir. Eğitim sonrasında olumlu algılarının olması ve bilgi düzeylerinin artması hastaların tedavi seçiminde doğru karar verebilmeleri amacıyla yapacakları eğitim ve danışmanlığa 1 şık tutacaktır.

\section{Kaynaklar}

1. World Health Organization. Global Status Report on Noncommunicable Diseases 2010. World Health Organization, 2011.

2. Jha V, Garcia-Garcia G, Iseki K, Li Z, Naicker S, et al. Chronic kidney disease: global dimension and perspectives. Lancet 2013;382 (9888):260-72.

3. Suleymanlar G, Utas C, Arinsoy T, Ates K, Altun B, et al. A population-based survey of Chronic REnal Disease In Turkey--the CREDIT study. Nephrol Dial Transplant. 2011;26(6):1862-71.

4. Kaptein AA, van Dijk S, Broadbent E, Falzon L, Thong M, et al. Behavioural research in patients with end-stage renal disease: a review and research agenda. Patient Educ. Couns. 2010; 81(1): 23-9.

5. Kidney Disease: Improving Global Outcomes (KDIGO) CKD Work Group. KDIGO 2012 clinical practice guideline for the evaluation and management of chronic kidney disease. Kidney Int Suppl. 2013;3:1-150. 
6. Süleymanlar G, Ateş K, Seyahi N. Ulusal Nefroloji, Diyaliz ve Transplantasyon Registry Raporu 2017, Türk Nefroloji Derneği Yayınları, Ankara, 2018.

7. Ersoy FF. Son Dönem Böbrek Yetmezliğinde Uygun Diyaliz Yönteminin Seçimi. Türkiye Klinikleri J Int Med Sci. 2005;1(21):88-92.

8. Harwood L, Clark AM. Understanding pre-dialysis modality decision-making: a meta-synthesis of qualitative studies. Int J Nurs Stud. 2013;50:109-20.

9. Chanouzas D, Ng KP, Fallouh B, Baharani J. What influences patient choice of treatment modality at the pre-dialysis stage? Nephrol Dial Transplant. 2012;27:1542-47.

10. Liang $\mathrm{CH}$, Yang $\mathrm{CY}, \mathrm{Lu} \mathrm{KC}$, Chu $\mathrm{P}$, Chen $\mathrm{CH}$, et al. Factors affecting peritoneal dialysis selection in Taiwanese patients with chronic kidney disease. Int Nurs Rev. 2011;58(4):463-9.

11. Blake PG, Quinn RR, Oliver MJ. Peritoneal dialysis and the process of modality selection. Perit Dial Int. 2013;33(3):233-41. 